\title{
Housewives' lifestyle and behavior of debt dependency on bank thitil
}

\section{Gaya hidup ibu rumah tangga dan perilaku ketergantungan terhadap bank thitil}

\author{
Suciawati Khusnul Khotimah ${ }^{1 *}$, Ketut Prasetyo ${ }^{2}$, Sukma Perdana Prasetya $^{2}$, \& Nasution ${ }^{2}$ \\ ${ }^{1}$ Master Program of Social Studies Education, State University of Surabaya \\ ${ }^{2}$ Faculty of Law and Social Sciences, State University of Surabaya \\ Address: ${ }^{1,2}$ Jalan Lidah Wetan, Lakarsantri, Surabaya, East Java, Indonesia 60231 \\ E-mail: suciawati.19012@mhs.unesa.ac.id
}

Article History: Received 12 October 2020; Accepted 14 February 2022; Published Online 02 March 2022

\begin{abstract}
The fulfillment of household needs can implement various strategies, including debt strategy. A money lending service becomes an attraction to fulfilling the needs of life. The money lending service on credit is known as bank thitil by Javanese. This study presents the factors that make housewives have a dependency behavior on bank thitil loans. This dependency behavior is examined from the perspective of the planned behavior theory by Ajzen. This study used a qualitative approach and the subjects of this study were housewives who have debt in bank thitil. Some factors encourage the dependency behavior of housewives on bank thitil loans. This research finds that the implementation of Ajzen's planned behavior theory in analyzing the factors of indebted housewives is integrated with some factors, including (1) the influence of attitudes that assume the bank thitil provides benefits, (2) subjective norms in the form of lifestyle and environmental vicinity, and (3) social control that supports the housewives in borrowing money from the bank thitil.
\end{abstract}

Keywords: debt behavior; dependency behavior; household needs; housewives

\begin{abstract}
Abstrak
Pemenuhan kebutuhan hidup oleh rumah tangga dilakukan dengan menerapkan banyak strategi, termasuk dengan cara berutang. Layanan peminjaman uang menjadi daya tarik dalam memenuhi kebutuhan hidup. Layanan peminjaman uang secara kredit lebih dikenal dengan sebutan bank thitil oleh masyarakat Jawa. Penelitian ini menyajikan serangkaian faktor yang membuat ibu rumah tangga memiliki perilaku ketergantungan terhadap pinjaman bank thitil. Perilaku ketergantungan ini dicermati dari perspektif teori perilaku terencana atau planned behaviour theory yang dikemukakan oleh Ajzen. Penelitian ini menggunakan pendekatan kualitatif. Subjek penelitian ini adalah ibu rumah tangga yang memiliki utang bank thitil. Terdapat serangkaian faktor yang mendorong ibu rumah tangga memiliki perilaku ketergantungan terhadap utang bank thitil. Penelitian ini menemukan bahwa implementasi teori perilaku terencana Ajzen dalam menganalisis faktor -faktor ibu rumah tangga berutang terintegrasi dengan faktor-faktor (1) pengaruh sikap yang menganggap bahwa utang bank thitil memberikan keuntungan, (2) norma subjektif yang berupa gaya hidup dan lingkungan sekitar, dan (3) kontrol sosial yang mendukung ibu rumah tangga dalam melakukan utang bank thitil.
\end{abstract}

Kata kunci: perilaku berutang; perilaku ketergantungan; pemenuhan kebutuhan rumah tangga; ibu rumah tangga

\section{Introduction}

Survival strategies to overcome the economic pressure and jolts can be grouped into three categories, including active strategy by utilizing all the potential possessed; passive strategy by minimizing the family expense or saving; and network strategy, which completes by using social networking to establish good relationships with the social environment or institutional environment (Novriadi 2017).

The concept of need fulfillment has been well-researched such as farmers completing the household needs by working on other people's land and still possible to borrow money from neighbors or landowners (Lestari et al. 2016). The strategy of need fulfillment of female street vendors implements the action strategy that utilizes time for a side hustle job, the passive scheme by cultivating a frugal living, and the network strategy taking advantage of the social environment by doing debts (Indahsari et al. 2018). 
Network strategy or doing debts became the most chosen strategy by the public when the active strategy and passive strategy are unperformed or unexecuted. A study by Silvia Szilagyiova (2015) regarding the decision to be in debt in fulfilling the needs of living in the UK shows that debt consumers are those who have lower incomes with plenty of living dependents. This is in line with a study conducted by Wajiha et al. (2018) about the reasons why people in Pakistan are in debt, including income instability and low savings. This study supplementarily shows that debt in young households is higher than in older households because young people tend to expend extra money.

Factors that influence debt behavior are relatively low income, the influence of the social environment, convenience by finance institutions, and the social lifestyle (Herispon 2018). It is relevant to a study conducted by Syafrini (2014) with fishermen as the subject that discover that strategies used when poor weather occurs include borrowing money from debt collectors by selling low-price catch to the debt collectors as the payment deal.

Money lending services on credit (payday) have experienced the fastest growth rates in the banking system since the 1900s (Lim et al. 2015). Lending money on credit applies to a non-fantastic value money loan system, short term, high interest, and simple terms and conditions (Skiba \& Tobacman 2011). Generally, lending money on credit has the characteristics of being flexible, lacking convoluted procedures, knowing each other individually, and not strictly monitored (Ningsih \& Zuroh 2010). Shortterm credit debt is not a new phenomenon. Numerous studies about credit loans in the UK reveal that credit loans were made due to the financial crisis, the significantly increased unemployment rate among young people, and an assumption that credit loans serve as an alternative to cover emergency costs, such as unexpected bills or basic needs (Szilagyiova 2015).

In Canada, since the 1990s, traditional banks have begun to appear and lend money to society with a loan period of 10 days (CPLA 2016). Data from the Community Financial Services Association of America in 2017 shows that short-term credit loans were provided to approximately 19 million households in America (Anderson \& Jackson 2018).

The lending money service on credit is the concern of many researchers about how the government's point of view and efforts in various countries regarding burdensome and detrimental elements to the society along with this transaction. The interest rate given on this loan transaction is high enough to gather criticism of this loan as a threat that harms the debtor. The existing regulations in credit institutions exploit consumers by covering actual lending costs with high-interest rates and point to the high-risk lending costs to strain low-income people yet have multiple and expensive access to credit (Bhutta et al. 2016).

Every country makes regulations that try to minimize credit that can harm society. The application of regulations prohibiting or regulating credit will lead to consumer welfare, which breaks the cycle of high debt rather than losses caused by limited consumer access to credit limited to other institutions (Weaver $\&$ Galperin 2014). The application of regulations to prohibit the provision of credit debt to the society is deemed treacherous to the community if the payments use a daily credit payment system and will lead to bankruptcy in the community (Morgan et al. 2012).

Columbia prohibits lending and considers the debtor's ability to repay and will refuse debtors who are unable to repay the total loan on time. It means the fund's source is provided if the creditors consider the consumer's monthly salary is sufficient with the payment agreement. However, if it does not meet the requirements of the stipulated regulations, the fund disbursement will not be given. Therefore, those people who use credit debt are not forced to look for more expensive credit sources by looking for alternative sources such as debt collectors, pawnshops, credit cards, etc. (Anderson \& Jackson 2018:4). 
Some states in the United States of America, such as North Carolina and New Hampshire, prohibit debt granting if there is no guarantee to repay the credit loans (Martin 2010). Another state like California constructs regulations by controlling the maximum arrears of $\$ 300$ (Pindus et al. 2011).

The characteristics of credit debt consumers are specifically experiencing household financial difficulties due to their young marital status and the risk of having debt, low income, and psychological shocks due to job losses that lead to excess debt (Giannetti et al. 2014). Debt is considered an alternative for someone to gratify their needs as a rational basis that encourages someone into debt (Cameron \& Golby in Dara 2017). Debt behavior consistently transpire on low-income people with immense expenditures (Cameron \& Golby in Nuruddin 2013).

Credit-lending services include individuals or groups who act as lenders or are commonly called loan sharks. Loan sharks are people who earn living by inflated money they lent (Pusat Bahasa Depdiknas 2005:949). Women are common targets of debt collectors because they are prone to poverty (Gunawan 2016). Indonesia poverty data in 2019 from the Statistics Indonesia, locally known as BPS indicate the poor in Indonesia are 24,785.87 people or 9.22\% (BPS 2020).

One of the government's capacities as a strategic solution in improving social welfare and economic equality is realized through the Permodalan Nasional Madani (PNM) program (Mardiana 2019). The PNM activities are providing capital, delivering capital, assisting management, dan other activities for micro, small, and medium enterprises, both from the government and private sector including training activities, etc. (PNM 2020). However, this is a fundamental weakness that assumes the poor only need capital, and the free assistance from the government is considered as a useless program to alleviate poverty (Ahmad 2010).

The complicated systems make people unmotivated to follow the administration system (Siboro 2015). People who always demand getting everything done fast create an opportunity for debt services or are referred to as bank thitil by the Javanese (Badri \& Actini 2012). Bank thitil provides loans with highinterest rates and each institution has different regulations for the loan interest rates and repayment schedule (Elisa \& Zuhroh 2017). The existence of other financial institutions such as state-owned banks, private-owned banks, microfinance institutions, or the national society empowerment program (PNPM) is still unable to eliminate the existence of loan shark transactions (Hudoro et al. 2014).

Despite the high-interest rates, bank thitil is still accepted by the poor because they are desperate to fulfill needs and assume that doing debt would help the economy at that moment (Ong et al. 2018). Generally, people taking debt are poor households with loads of necessity, but earning a small income, stimulating huge consumer credit (Pressman \& Scott 2009).

Housewives as the ones responsible for managing family finances face difficulties when the money from the husbands is not enough to fulfill their daily needs. Limitations force housewives to make strategies by borrowing money from the lenders (Bourdieu in Shofa 2018). Utilizing debt credit is a way for the lower class who cannot fulfill their needs with the agreed contracts between the borrower and the lenders or debt collectors (Suryono et al. 2015). Debt in fulfilling family needs is connected to stance and personality factors that motivate someone in deciding to do debt and consumptive behavior (Cosma in Shohib 2015).

Based on preliminary observations carried out by the researchers in Magersari Village, Krian District, Sidoarjo Regency, many housewives deal with bank thitil. The problems that arise as a consequence of the loan system are people who engage in loans without understanding their capacity to repay the loans and interest. This situation makes people find ways to pay off debts by looking for other loan sources and that creates a never-ending loan cycle. Therefore, they implemented a system of paying debts by way of debt. Another problem arising is that the wives secretly carry out transactions without their husbands knowing. 
This study related to housewives' debt-dependent behavior through bank thitil is interesting because it examines social problems existing in society. The concept of social problems emphasizes the gap between das sein and das sollen or the discrepancy between expectations and reality (Supardin 2014). The gap in this research is when housewives are unable to fulfill their life needs and it stimulates them to borrow money on bank thitil that offers credit with a high amount of interest.

The next argumentation is related to the focus of analysis on social problems which emphasizes the causes of these problems. This study focused on the research problem to discover the encouraging factors of housewives to have a debt-dependent behavior on bank thitil. The next argument is related to the manifest and social problems in the housewives' debt dependency on bank thitil which is considered wrong by other people in society because it stimulates conflicts between debt collectors and the housewives, debt collectors and husbands, and among housewives who have debt.

The theory used to analyze the problems in this study is the planned behavior theory by Ajzen (1991). This theory explains that personal behavior is predicted through intention, which is influenced by attitudes toward behavior, subjective norms, and perceived behavioral control. This theory is modified by adding the perceived control behavior as an intention predictor. Therefore, the definition of influenced intention by attitudes towards behavior is to the extent a person can evaluate whether a behavior is beneficial or not. Subjective norms refer to the social pressure sensed by individuals to do or not to do the actions, and behavior control (Ajzen 1991).

\section{Research Method}

The study used a qualitative approach with a case study research design. The study case is one of the social science research methods, while the qualitative approach is a research method to examine the conditions of the natural object (as experiments opposed), researcher as the key instrument, data collection techniques carried out by triangulation (combined), inductive data analysis, and the results of qualitative research that emphasize the meaning rather than generalization (Sugiyono 2013).

The study subjects are six housewives in Magersari Village, Krian District, Sidoarjo Regency who use loan services on non-formal institutions. The subjects are housewives who owe debts to non-formal banking institutions (bank thitil) and clandestinely hide the debts from their husbands. The majority uses bank thitil services are unemployed housewives with a non-steady income. Therefore, they only depend on the money from their husbands. Their husbands' jobs are very diverse. Several get a fixed salary every month, such as working for inter-provincial transportation service companies, company director drivers, factory workers, etc. Others work in the informal sector with a non-steady salary every month such as pedicab drivers, tire repair services, and others.

The data collection technique included observation, in-depth interviews, and documentation. The data processing technique uses triangulation by combining three methods to study the interrelated phenomena with the required data sources. Data processing is to process and prepare data for analysis, and data interview transcript is typed and sorted according to study needs. Subsequently, data reading is done to reflect the overall meaning. Next, data interpreting is done by linking the theory. Afterward, the data are interpreted and presented in narratives as the results of the research.

\section{Results and Discussion}

\section{The attitude towards debt-dependant behaviour on bank thitil}

Attitudes towards a behavior are determined by a person's beliefs and the consequences of behavior that lead to judgment. The borrowers are sure to get a positive or negative attitude towards debt. The study results show that the housewives who owe to bank thitil in Magersari Village, Krian District, Sidoarjo, have the intention of debt into real action because they believe positively towards the debt behavior. The 
housewives believe that debt is the best solution to overcome their financial problems. The intention influenced by expenditure for needs is not balanced with the income.

"The salary drops every month, enough to buy rice for one month, but not for sudden needs like unexpected school expenses or visiting sick people/neighbors, and other sudden needs. That's why I use debt to fulfill the life necessities." (Interview with MUC, 38 years old)

Debt intentions are followed by their actual actions in choosing a bank thitil as a solution in providing funds due to the administration's ease. The benefit is the quick process and the installment payments (debt is paid regularly in installment). Therefore, they think that the bank thitil is the best solution among other money lending institutions. The dependent behavior on bank thitil loans is due to several factors. Those factors are the high expense of daily needs, administration process easiness, and the lifestyle. The housewives choose to hide their habits from their husbands with the consideration that the husbands do not support their actions.

"If we already know the debt collector, everything is easy. Debt collectors pass in front of our house then we will get a loan of money. But, if we do not know each other personally, we just need to give the identity card copies then the money will be provided." (Interview with ALF, 28 years old)

Not only one debt collectors come to Magersari Village daily. Numerous of them come daily and they come from various institutions. The offer is an agreement between two parties regarding the amount of money, the amount of interest offered, and the period for the payment. The offer is attractive for the housewives to take out a loan from the bank thitil despite no guarantee whether they could pay off the money and interest. They use the system of paying debts by way of debt. They obtained money to pay the previous debts from the new debt. As a result, they do not only owe to one institution but several institutions with a different system.

"Sometimes I do not need money at that time, but the person (the debt collector nickname) still offered me. I take it, just in case of any unexpected needs later. What a waste if I do not take it because of the cheap interest, I just need to pay the installment ten times regularly. I will think about the money to repay later." (Interview with ARS, 56 years old).

That explanation shows that the housewives' positive perception towards the bank thitil influenced their behavior. Therefore, they have a behavioral dependency to take debt from banks thitil. This behavior is influenced by the personal attitude, a positive attitude towards the object, and pursued by the positive behavior related to the debt (Livingstone \& Lunt 1992).

The result is in line with the planned behavior theory (Ajzen 2006) that discusses attitudes towards behavior are determined by beliefs about the consequences of a behavior. The principles are related to the individual's subjective evaluation of the surrounding environment by linking certain behaviors with various benefits or disadvantages and might be obtained if the individual does or does not do it. Housewives who use the bank thitil service believe that the bank thitil helps them during the economic loss by offering easy administration to get loan money.

\section{Subjective norms against the loan dependence on bank thitil}

The social environment influences dependency behavior against the bank thitil determined by the normative idea. The scheme of the social-environment relations makes the dissatisfaction on standards that exist in their life. As a result, the dependency behavior started from the dissatisfaction with the lifestyle, which then suggests determining the choice between the pros or cons in doing transactions of debt in bank thitil. 
Lifestyle is one factor that influences housewives' debt dependency behavior. The lifestyle implies their perspective to fulfill all their long-craved needs. These needs are not only primary needs but also secondary and tertiary needs of the housewives. Nonetheless, they are cognizant that paying interest to a bank thitil will be more expensive than buying goods without using debt money.

"The money that I got from the loan is used to buy a wardrobe, hybrid mattress (springbed), clothes, and others. I only buy these items using the loan money because the main income is only enough for basic needs, so taking debt is worth it." (Interview with ETR, 34 years old)

Another lifestyle shown are habits of buying expensive food and disregarding the income ability. They presume that their wishes must be provided, especially the children's wishes.

"Sometimes, my son requests delicious dishes with expensive ingredients. As a parent, I cannot refuse my son's request. Sometimes, my children ask to order through online food delivery. If I refuse, he does not want to eat. Although we run out of money, we still accept the child's request. So, we use the bank thitil service." (Interview FIT, 44 years old)

The housewives in Magersari Village with debt dependency on the bank thitil have members of a group with the same frame of mind regarding the debt. They have both offline and online groups to exchange bank thitil loans information. They do not owe only to one institution but also to several institutions. The group is also a discussion forum to discuss how to pay off the debt strategies. The strategy mostly is paying debts by way of debt.

"I am not the only one using the bank thitil services. A bunch of neighbors too. We have an online group on WhatsApp to discuss the debt. Sometimes we do not have money to pay the debt. The group's members will provide information on loan funds from another debt lending. So, the cycle is always like that." (Interview with MIN, 40 years old)

The exposition shows the strong support comes from the surrounding environment, including their children, neighbors, friends, and another social environment. This support encourages the housewives' behavioral dependency on bank thitil (Lindern \& Mosler 2014). It is associated with the planned behavior theory (Ajzen 2006) that subjective norms are based on individual perceptions towards expectations from influential people in their lives. Herewith behavioral dependency on bank thitil, the housewives have influential people supporting this, including people around them such as family and neighbors influencing their lifestyle.

\section{Behavior control of housewives' dependency on bank thitil}

The power existing in a person as a stimulus or an obstacle can be a strong or weak behavioral control. Therefore, it can inhibit a person from behaving. This study found that the inhibiting factor for housewives making debt loans was the husband's permission. Several husbands did not permit to take debt from the bank thitil.

The housewives' debt activities are not known by their husbands. Thereupon, the housewives implement a strategy to disguise the transaction with the bank thitil from their husbands. Several factors cause this incident. The husband thinks that the money given to his wife is sufficient. They do not want to know if the money given is not enough, thinking their wives must be able to manage family finances by balancing income and spending.

"My husband does not understand how much money to spend for daily needs. The point is that the money must be sufficient. We fought triggered by my request for money and he did not have any, then he said the money must be managed properly and should be enough to suffice the needs. So, the best solution is to borrow money from the bank thitil. But if my husband finds out, he gets angry too." (Interview with MUC, 38 years old). 
The second factor is the husband's self-distrust when the wife is in debt. They care about what the neighbors think if the husband is unable to suffice the needs. These considerations decrease the husband's self-esteem.

"I once got caught when a bank thitil debt collector was charging at my home when my husband was at home too. He was so angry. He said that his self-esteem would decrease because he could not provide enough needs for his wife." (Interview with ETR, 34 years old).

Regardless of the husband forbids doing debt transactions at bank thitil, the housewife still does it. It is because the housewife is required to be competent in managing finances, although the money she gets from her husband is not enough. Furthermore, the housewife is afraid of her husband's bad judgment. The husband thinks that the wife is incompetent in taking care of household finances. So, this is this housewife's reason to clandestinely the debt from her husband.

The strategy to deceive the husband is by prohibiting the debt collectors from collecting debts when the husband is at home. The housewive will deposit their debt payment money with other wives that have identical business with the debt collector. The debt collectors will understand this because they will not cause a commotion with the husband. These debt collectors constantly complain about the cynical attitude they receive from their husbands. There was even ensue an argument between the two of them. Therefore, this indebted housewife and the group will discuss to perpetuate the transaction.

Behavioral control can affect the intention into debt. Behavior control is positively related to debt settlement behavior (Denan et al. 2015). From the explanation of the social control, even if the husbands prohibit to owe from the bank thitil the housewives still have reasons to owe. Therefore, they do not bother about the ban. Aligned with behavior control theory, when someone has an intention with only a minor obstacle that gets in the way, that person would still actualize it into real action. Otherwise, if the preponderant hindrance gets in the way, the chance of intentions becoming into real action is smaller (Ajzen 1991).

Behavioral control in the theory of planned behavior (Ajzen 2006) is defined as an individual's perception of the ease or difficulty of realizing a specific behavior. High control perception's individuals will be driven and try to actualize it because, with the existent propositions, they can overcome hardship. It is consistent with the reasons described by housewives for being indebted to bank thitil due to the opportunity to take the debt from the bank thitil during the crisis.

\section{Conclusion}

The housewives in Magersari Village use debt strategies to fulfilling the needs of life. They choose to owe to bank thitil. Bank thitil is debt lending services on credit. The housewives choose bank thitil as a solution in providing funds due to the administration ease. As a result, they think that the bank thitil is the best solution among other money lending institutions. Lifestyle is also one of the reasons for housewives' debt dependency behavior. They are degrading their income ability because they presume that their wishes must be provided. The housewives' debt activities are not known by their husbands because they do not want a commotion if their husbands find out. The husbands believe that their wives must be able to manage family finances by making balancing income and expenses.

The factors that support the behavior of dependency on debt are related to the theory of planned behavior by Ajzen. The theory about planned behavior includes several aspects that support someone to behave such as attitudes towards the behavior, subjective norms, and behavioral control. It is based on intentions of giving a positive evaluation of bank thitil, and then on subjective norms through lifestyle factors and the groups support that have the same matters. Afterward, the social controls of the low income are compared with the high expense. This study concludes that bank thitil is the best solution in overcoming the housewives' economic problems. Regardless of the detrimental things such as high bank interest, they still choose to be in debt. 


\section{References}

Ahmad T, Erowati D, \& Wijayanto (2010) Upaya penanggulangan kemiskinan berbasis pemberdayaan masyarakat lokal. Politika: Jurnal Ilmu Politik 1 (1):134-158.

Ajzen I (1991) The theory of planned behavior. Organizational Behavior and Human Decision Processes 50 (2):179-211. https://doi.org/10.1016/0749-5978(91)90020-T.

Ajzen I (2006) Perceived behavioral control, self-efficacy, locus of control, and the theory of planned behavior. Journal of Applied Social Psychology (32) 4:665-683. https://doi. org/10.1111/j.1559-1816.2002.tb00236.x.

Anderson MH \& Jackson R (2018) Evaluating options for the regulation of payday loans. The Journal of Applied Business Research 34 (1):131-142. https://doi.org/10.19030/jabr.v34i1.10100.

Badri S \& Actini CN (2012) Implikasi operasional bank keliling terhadap eksistensi koperasi pengusaha batik Tembayat Kecamatan Bayat Klaten (studi empirik dalam mekanisme penyaluran kredit). Jurnal Orasi Bisnis 8 (2):27-36.

Bhutta N, Goldin J, \& Homonoff T (2016) Consumer borrowing after payday loan bans. Journal of Law and Economics 59 (1):225-229. https://doi.org/10.1086/686033.

BPS (2020) Profil kemiskinan di Indonesia. [Accessed 07 March 2020]. https://www.bps.go.id/website/ images/Profil-Kemiskinan-di-Indonesia-September-2020-ind.jpg.

CPLA (2016) Canadian Payday Loan Association (CPLA). [Accessed 07 April 2020]. https://www. cpla-acps.ca/.

Dara UD (2017) Hutang piutang di kalangan buruh perempuan di Desa Jetis Kecamatan Jetis Kabupaten Mojokerto. Thesis, Universitas Airlangga, Surabaya.

Denan Z, Othman AA, Ishak MNI, Kamal MFM, \& Hasan MH (2015) The theory of planned behavior and self-identity factors drive graduates to be indebtedness. International Journal of Social Science and Humanity 5 (4):345-346. https://doi.org/10.7763/IJSSH.2015.V5.477.

Elisa R \& Zuhroh I (2017) Peran bank thitil dalam kehidupan masarakat ekonomi lemah (studi kasus penyaluran kredit oleh bank thitil terhadap pedagang sayur di Pasar Kesamben Kabupaten Blitar). Jurnal Ilmu Ekonomi 1 (1):1-15. https://doi.org/10.22219/jie.v1i1.5399.

Giannetti C, Madia M, \& Moretti L (2014) Job insecurity and financial distress. Applied Financial Economics 24 (4):219-233. https://doi.org/10.2139/ssrn.1991899.

Gunawan R (2016) Kemiskinan perempuan dan renternir di perkotaan serta penangulangannya. In: Berbincang tentang Perempuan dan Pendidikan untuk Kesetaraan Gender. Pusat Pelayanan tepadu Pemberdayaan Perempuan dan Anak. http://repository.uhamka.ac.id/10/.

Herispon (2018) Analisis faktor-faktor yang mempengaruhi perilaku utang rumah tangga (sebuah kajian literatur). Jurnal Ilmiah Ekonomi dan Bisnis 15 (2):89-101 https://doi.org/10.31849/jieb. v15i2.1156.

Hudoro P, Findi M, \& Ayyubi SE (2014) Faktor-faktor yang memengaruhi pemilihan pinjaman dengan sistem rente di desa studi kasus: Desa Panulisan Timur Kecamatan Dayeuhulur Kabupaten Cilacap (periode tahun 2013-2014). Jurnal Al-Muzara'ah 2 (2):196-217.

Indahsari N, Purwaka, \& Hartati S (2018) Strategi bertahan hidup perempuan pedagang asongan (studi kasus perempuan pedagang asongan di Stasiun Selero Kelurahan Lubuklinggau Ilir Kecamatan Lubuklinggau Barat II, Kota Lubuklinggau, Provinsi Sumatera Selatan). Jurnal Sosiologi Nusantara 4 (1):139-151. https://doi.org/10.33369/jsn.4.1.39-52.

Lestari Y, Hartati S, \& Nopianti H (2016) Pemenuhan kebutuhan hidup rumah tangga petani miskin (studi kasus pada petani penggarap di Dusun II Talang Watas Desa Muara Langkap Kecamatan Bermani Ilir, Kabupaten Kepahiang). Jurnal Sosiologi Nusantara 2 (2):94-103. https://doi.org/10.33369/ jsn.2.2.94-103.

Lim Y, Bickham T, Dinecola CM, Broussard J, Webber BE, \& Gregory A (2015) Payday loan use and consumer wellbeing: What consumers and social workers need to know about payday loans. Journal of Poverty 18 (4):379-398. https://doi.org/10.1080/10875549.2014.951906.

Lindern E \& Mosler H (2014) Insights into fisheries management practices: Using the theory of planned behavior to explain fish stocking among a sample of Swiss anglers. Plos One 9 (12):1-20. 
Livingstone SM \& Lunt PK (1992) Predicting personal debt and debt repayment: Psychological, social, and economic determinants. Journal of Economic Psychology 13 (1):111-134. https://doi. org/10.1016/0167-4870(92)90055-C.

Mardiana (2019) Faktor-faktor yang meyebabkan masyarakat memilih pembiayaan di PT Permodalan Nasional Madani (Persero) cabang Kota Bengkulu. Thesis, Universitas Islam Negeri Fatmawati Sukarno Bengkulu, Bengkulu.

Martin N (2010) 1,000\% interest-good while supplies last: A study of payday loan practices and solutions. Arizona Law Review 52 (3):563-622.

Morgan DP, Strain MR, \& Seblani I (2012) How payday credit access affects overdrafts and other outcomes. Journal of Money, Credit and Banking 44 (2-3):519-31. https://doi.org/10.1111/j.15384616.2011.00499.x.

Ningsih D \& Zuroh I (2010) Analisis permintaan kredit investasi pada bank swasta nasional di Jawa Timur. Jurnal Ekonomi Pembangunan 8 (2):345-356. https://doi.org/10.22219/jep.v8i2.3608.

Novriadi (2017) Strategi bertahan hidup rumah tangga pendulang emas Desa Seberang Sungai Kecamatan Gunung Toar Kabupaten Kuantan Singingi. JOM FISIP 4 (2):1-15.

Nuruddin IH (2013) Studi fenomenologi perilaku berhutang. Thesis, Universitas Gadjah Mada, Yogyakarta.

Ong Q, Theseira W, \& Ng IYH (2018) Reducing debt improves psychological functioning and changes decision-making in the poor. Proceedings of the National Academy of Sciences 116 (15):72447249. https://doi.org/10.1073/pnas.1810901116.

Pindus N, Kuehn, \& Brash R (2011) State restrictions on small-dollar loans and financial services, 2004-2009 review. Urban Institute, 23 February. [Accessed 27 March 2020]. https://www.urban. org/research/publication/state-restrictions-small-dollar-loans-and-financial-services-2004-2009summary-documentation-and-data.

PNM (2020) PNM Grup. [Accessed 07 March 2020]. https://www.pnm.co.id/pages/pnm-group.

Pressman S \& Scott RH (2009) Who are the debt poor? Journal of Economic Issue 43 (2):423-432. https://doi.org/10.2753/JEI0021-3624430215.

Pusat Bahasa Depdiknas (2005) Kamus Besar Bahasa Indonesia. Jakarta: Balai Pustaka.

Shofa DA (2018) "Petak umpet" istri studi tentang relasi kuasa di Manukan Kecamatan Tandes Kota Surabaya. Thesis, Universitas Airlangga, Surabaya.

Shohib M (2015) Sikap terhadap uang dan perilaku berhutang. Jurnal Ilmiah Psikologi Terapan 3 (1):132-143.

Siboro IK (2015) Rentenir (analisis terhadap fungsi pinjaman berbunga dalam masyarakat Rokan Hilir Kecamatan Bagan Sinembah Desa Bagan Batu). JOM FISIP 2 (2):1-15.

Skiba PM \& Tobacman J (2008) Payday loans, uncertainty, and discounting: Explaining patterns of borrowing, repayment, and default. Vanderbilt Law and Economics Research Paper No. 08-33. http://dx.doi.org/10.2139/ssrn.1319751.

Sugiyono (2013) Memahami Penelitian Kualitatif. Bandung: Penerbit Alfabeta.

Supardin (2014) Analisis sosiologi hukum dalam realitas fikih sosial. Jurnal Al-Daulah 3 (1):80-90. https://doi.org/10.24252/ad.v3i1.1523.

Suryono ANRP, Wijaya M, \& Demartoto A (2015) Perilaku ibu rumah tangga pemakai kredit barang keliling (Mindring: Studi kasus pada ibu rumah tangga pemakai kredit barang keliling mindring). Jurnal Analisa Sosiologi 4 (2):60-67. https://doi.org/10.20961/jas.v4i2.17438.

Syafrini D (2014) Nelayan vs rentenir, studi ketergantungan nelayan terhadap rentenir pada masyarakat pesisir. Jurnal Ilmu Sosial Mamangan 1 (2):67-74. https://doi.org/10.22202/mamangan.v3i2.99.

Szilagyiova S (2015) The effect of payday loans on financial distress in the UK. Procedia Economics and Finance 30:842-847. https://doi.org/10.1016/S2212-5671(15)01334-9.

Wajiha H, Ismail NA, \& Satar NM (2018) Household debt in different age cohorts: A multilevel study. Cogent Economics Finance 6 (1):1-6. https://doi.org/10.1080/23322039.2018.1455406.

Weaver A \& Galperin V (2014) Payday lending and the demand for alternative financial services. Community Development Issue Brief 4:1-9. https://doi.org/10.2139/ssrn.2494426. 